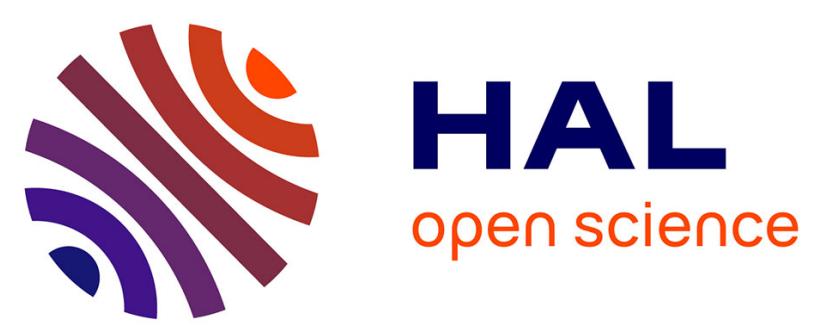

\title{
Influence of reagents choice (buffer, acid and inert salt) on triiodide production in the Villermaux-Dushman method applied to a stirred vessel
} Carlos Baqueiro, Nelson Ibaseta, Pierrette Guichardon, Laurent Falk

\section{- To cite this version:}

Carlos Baqueiro, Nelson Ibaseta, Pierrette Guichardon, Laurent Falk. Influence of reagents choice (buffer, acid and inert salt) on triiodide production in the Villermaux-Dushman method applied to a stirred vessel. Chemical Engineering Research and Design, 2018, 136, pp.25-31. 10.1016/j.cherd.2018.04.017 . hal-01771934

\section{HAL Id: hal-01771934 \\ https://hal.science/hal-01771934}

Submitted on 22 May 2018

HAL is a multi-disciplinary open access archive for the deposit and dissemination of scientific research documents, whether they are published or not. The documents may come from teaching and research institutions in France or abroad, or from public or private research centers.
L'archive ouverte pluridisciplinaire HAL, est destinée au dépôt et à la diffusion de documents scientifiques de niveau recherche, publiés ou non, émanant des établissements d'enseignement et de recherche français ou étrangers, des laboratoires publics ou privés. 


\section{Accepted Manuscript}

Title: INFLUENCE OF REAGENTS CHOICE (BUFFER, ACID AND INERT SALT) ON TRIIODIDE PRODUCTION IN THE VILLERMAUX-DUSHMAN METHOD APPLIED TO A STIRRED VESSEL

Authors: Carlos Baqueiro, Nelson Ibaseta, Pierrette

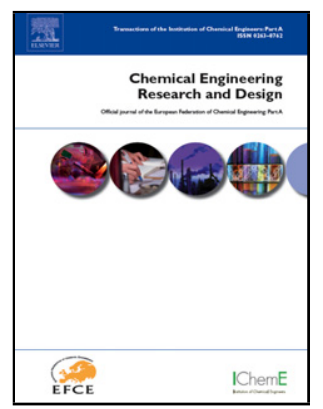

Guichardon, Laurent Falk

PII: S0263-8762(18)30191-6

DOI: https://doi.org/10.1016/j.cherd.2018.04.017

Reference: CHERD 3134

To appear in:

Received date: $\quad$ 7-3-2018

Revised date: 6-4-2018

Accepted date: $\quad 10-4-2018$

Please cite this article as: Baqueiro, Carlos, Ibaseta, Nelson, Guichardon, Pierrette, Falk, Laurent, INFLUENCE OF REAGENTS CHOICE (BUFFER, ACID AND INERT SALT) ON TRIIODIDE PRODUCTION IN THE VILLERMAUX-DUSHMAN METHOD APPLIED TO A STIRRED VESSEL.Chemical Engineering Research and Design https://doi.org/10.1016/j.cherd.2018.04.017

This is a PDF file of an unedited manuscript that has been accepted for publication. As a service to our customers we are providing this early version of the manuscript. The manuscript will undergo copyediting, typesetting, and review of the resulting proof before it is published in its final form. Please note that during the production process errors may be discovered which could affect the content, and all legal disclaimers that apply to the journal pertain. 


\section{INFLUENCE OF REAGENTS CHOICE (BUFFER, ACID AND INERT SALT) ON TRIIODIDE PRODUCTION IN THE VILLERMAUX-DUSHMAN METHOD APPLIED TO A STIRRED VESSEL}

Carlos Baqueiro ${ }^{1}$, Nelson Ibaseta ${ }^{1, *}$, Pierrette Guichardon ${ }^{1}$, Laurent Falk ${ }^{2,3}$

${ }^{1}$ Aix Marseille Univ, CNRS, Centrale Marseille, M2P2, Marseille, France.

2 Univ Lorraine, Lab React \& Genie Proc, UMR 7274, Nancy, France

${ }^{3}$ CNRS, Lab React \& Genie Proc, UMR 7274, Nancy, France

* Corresponding author : Ecole Centrale Marseille, M2P2, 38, rue Frédéric Joliot Curie, 13451 Marseille Cedex 13, France. E-mail : Nelson.lbaseta@centrale-marseille.fr

\section{Graphical abstract}

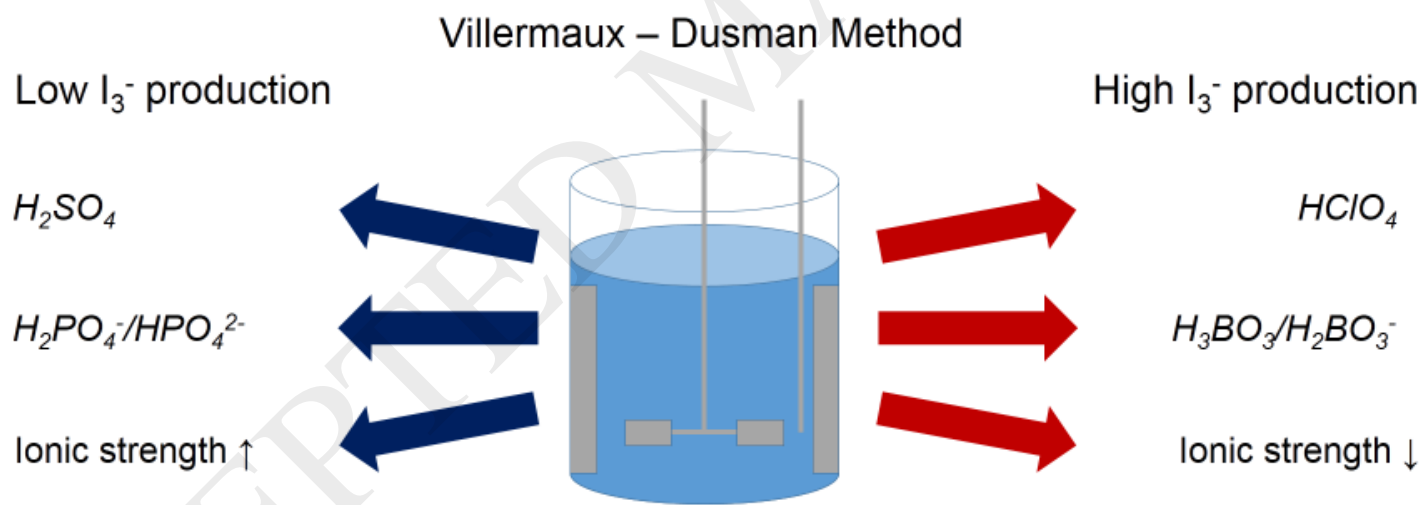

Highlights

- The influence of the reagents choice in the Villermaux Dushman test is studied

- Phosphate buffers lead to lower $\mathrm{I}_{3}^{-}$production that borate buffers

- $\mathrm{I}_{3}{ }^{-}$production is slightly influenced by the ionic strength

- Both acids and buffers can be used for qualitative studies

- The $\mathrm{pK}_{\mathrm{a}}$ of $\mathrm{H}_{2} \mathrm{SO}_{4}$ and $\mathrm{H}_{3} \mathrm{PO}_{4}$ should be considered in micromixing time estimations 


\section{Abstract}

This work studies how deeply the reagents choice influences micromixing characterisation by the Villermaux-Dushman method, when applying it to a 1 litre stainless steel standard vessel with two baffles, stirred by an inclined blade turbine. For the first time, borate and phosphate buffer are compared on their use in the method. It is observed that triiodide production is higher when borate buffer is used. Moreover, perchloric acid leads to higher triiodide production than sulphuric acid, when injecting the same concentration of both acids. Finally, the influence of the ionic strength is also studied, since there has been a great deal of controversy about it over the last years. The results show that the ionic strength affects triiodide production, although relatively slightly. Advice concerning the choice of the reagents is given in conclusion.

\section{Keywords}

Micromixing, Villermaux-Dushman, lodide iodate method, mixing characterization

\section{Introduction}

Micromixing (Bałdyga and Pohorecki, 1995) is defined as mixing at the molecular scale, that is, below the Kolmogorov scale. It plays a main role when dealing with fast reactions: polymerization reactions, fast competitive-consecutive and fast parallel reactions, as well as reactive crystallizations (precipitations). In all these applications, the final product obtained depends on the micromixing rate. Hence, a special focus was given to developing micromixing characterization methods at the end of the $20^{\text {th }}$ century (Bourne et al, 1992; Fournier et al, 1996a). The iodide iodate method, also called Villermaux-Dushman method, has probably become the main micromixing characterization method, thanks to a lower cost and easier product manipulation (Guichardon et al, 2001). Since it was proposed by Fournier et al (1996a) and modified by Guichardon and Falk (2000), the method has been widely used for selection of the injection point and comparison of the micromixing quality obtained using new devices or removing baffles (Rousseaux et al, 1999; Assirelli et al, 2002; Assirelli et al, 2005; Assirelli et al, 2008a) and determination of the local dissipative rate (Schaer et al, 1999; Assirelli et al, 2008b; Nouri et al, 2008; Habchi et al, 2014). With the development of micromixers during the 2000s (Hessel et al, 2005), the method has also been adapted for their characterization (Panić et al, 2004; Kölbl et al, 2008; Commenge and Falk, 2011).

This method is based on the competition between two reactions: an instantaneous neutralization reaction (reaction 1 , where $\mathrm{B}^{-}$is a base), and the Dushman reaction (Dushman, 1904), which is a fast (but slower than reaction 1) comproportionation reaction (reaction 2).

$$
\begin{array}{ll}
\mathrm{H}^{+}+\mathrm{B}^{-} \rightarrow \mathrm{HB} & \text { (reaction 1) } \\
6 \mathrm{H}^{+}+5 \mathrm{I}^{-}+\mathrm{IO}_{3}^{-} \rightarrow 3 \mathrm{I}_{2}+3 \mathrm{H}_{2} \mathrm{O} & \text { (reaction 2) }
\end{array}
$$

When some acid is fed in stoichiometric default in an aqueous basic solution containing an appropriate pre-mixture of iodide, iodate and $\mathrm{B}^{-}$anions, the products obtained depend on the quality of micromixing. In the case of perfect mixing conditions, all the protons will be consumed by the base according to reaction 1. In the case of imperfect mixing, there will be a local lack of base, protons will react with iodide and iodate anions, and some iodine will be produced. 
lodine will then be involved in a quasi-instantaneous equilibrium with triiodide (reaction 3), as follows:

$$
\mathrm{I}^{-}+\mathrm{I}_{2} \leftrightarrow \mathrm{I}^{-}
$$

(reaction 3)

Hence, triiodide concentration, which can be easily measured by UV-visible spectrophotometry, can be used to characterize the quality of micromixing.

The original method (Fournier et al, 1996; Guichardon and Falk, 2000) used sulphuric acid and borate buffer. However, during the last ten years, different adaptations of the method have been proposed, most of them concerning the use of a different acid and/or buffer. Kölbl and Schmidt-Lehr (2010) proposed replacing sulphuric acid with perchloric acid for quantitative treatment, arguing that sulphuric acid may not be completely dissociated. Hydrochloric acid has even been used (Ehrfeld et al, 1999), despite the catalytic effect of chloride anions on the Dushman reaction (Schmitz, 1999). On the other hand, Pinot et al (2014) proposed using a phosphate buffer $\left(\mathrm{HPO}_{4}^{-2} / \mathrm{H}_{2} \mathrm{PO}_{4}^{-}\right)$instead of the borate buffer $\left(\mathrm{H}_{2} \mathrm{BO}_{3}{ }^{-} / \mathrm{H}_{3} \mathrm{BO}_{3}\right)$ because of the toxicity of borate. However, it is worth noting that the influence of these choices (especially the choice of the buffer) have not been deeply analysed. The present work aims at comparing results obtained using both acids and both buffers, and then proposing the most adapted combination for a given application.

\section{Materials and methods}

The following compounds were used without further purification in the preparation of the solutions: $\mathrm{H}_{2} \mathrm{SO}_{4}$ (VWR, GPR Rectapur), $\mathrm{HClO}_{4}$ (Fisher chemical, laboratory grade), $\mathrm{Na}_{2} \mathrm{SO}_{4}$ (Alfa Aesar, ACS reagent grade), $\mathrm{NaClO}_{4}$ (Acros Organics, extra pure), $\mathrm{NaOH}$ (Acros Organics, ACS reagent grade), $\mathrm{H}_{3} \mathrm{BO}_{3}$ (Acros Organics, ACS reagent grade), $\mathrm{Na}_{2} \mathrm{HPO}_{4}$ (Acros Organics, extra pure), $\mathrm{NaH}_{2} \mathrm{PO}_{4}$ (Acros Organics, ACS reagent grade), $\mathrm{KI}$ (Acros Organics, ACS reagent grade) and $\mathrm{KIO}_{3}$ (Acros Organics, ACS reagent grade). Acid solutions were obtained by dilution of $\mathrm{H}_{2} \mathrm{SO}_{4}$ or $\mathrm{HClO}_{4}$ in distilled water, in some cases adding $\mathrm{Na}_{2} \mathrm{SO}_{4}$ or $\mathrm{NaClO}_{4}$, whereas pre-mixture solutions were prepared by dissolving $\mathrm{KI}, \mathrm{KIO}_{3}, \mathrm{NaOH}$ and $\mathrm{H}_{3} \mathrm{BO}_{3}$ (for borate buffer solutions) or $\mathrm{KI}, \mathrm{KIO}_{3}, \mathrm{Na}_{2} \mathrm{HPO}_{4}$ and $\mathrm{NaH}_{2} \mathrm{PO}_{4}$ (for phosphate buffer solutions) in distilled water. The concentrations for each experiment set are shown in Table 1.

Table 1 : Experimental concentration sets used for acid solutions and pre-mixture solutions. All concentrations are in $\mathrm{mol} / \mathrm{L}$. $\left(^{*}\right)$ : In experiment sets 16 to $19, \mathrm{NaClO}_{4}$ was added to the premixture solution

\begin{tabular}{|c|c|c|c|c|c|c|c|c|}
\hline & \multicolumn{4}{|c|}{ Acid solution } & \multicolumn{4}{|c|}{ Pre-mixture solution } \\
\hline Set & {$\left[\mathrm{H}_{2} \mathrm{SO}_{4}\right]$} & {$\left[\mathrm{HClO}_{4}\right]$} & {$\left[\mathrm{Na}_{2} \mathrm{SO}_{4}\right]$} & {$\left[\mathrm{NaClO}_{4}\right]$} & $\begin{array}{l}{\left[\mathrm{NaH}_{2} \mathrm{BO}_{3}\right.} \\
] \\
\&\left[\mathrm{H}_{3} \mathrm{BO}_{3}\right]\end{array}$ & $\begin{array}{l}{\left[\mathrm{Na}_{2} \mathrm{HPO}_{4}\right.} \\
] \\
\& \\
{\left[\mathrm{NaH}_{2} \mathrm{PO}_{4}\right.}\end{array}$ & {$[\mathrm{KI}]$} & {$\left[\mathrm{KIO}_{3}\right]$} \\
\hline 1 & 0.5 & - & - & - & 0.1 each & - & \multirow{7}{*}{0.0116} & \multirow{7}{*}{0.00233} \\
\hline 2 & 0.5 & - & - & - & - & 0.1 each & & \\
\hline 3 & - & 1 & - & - & 0.1 each & - & & \\
\hline 4 & - & 0.5 & - & - & 0.1 each & - & & \\
\hline 5 & - & 1 & - & - & - & 0.1 each & & \\
\hline 6 & - & 1 & 0.5 & - & 0.1 each & - & & \\
\hline 7 & - & 1 & 0.5 & - & - & 0.1 each & & \\
\hline
\end{tabular}




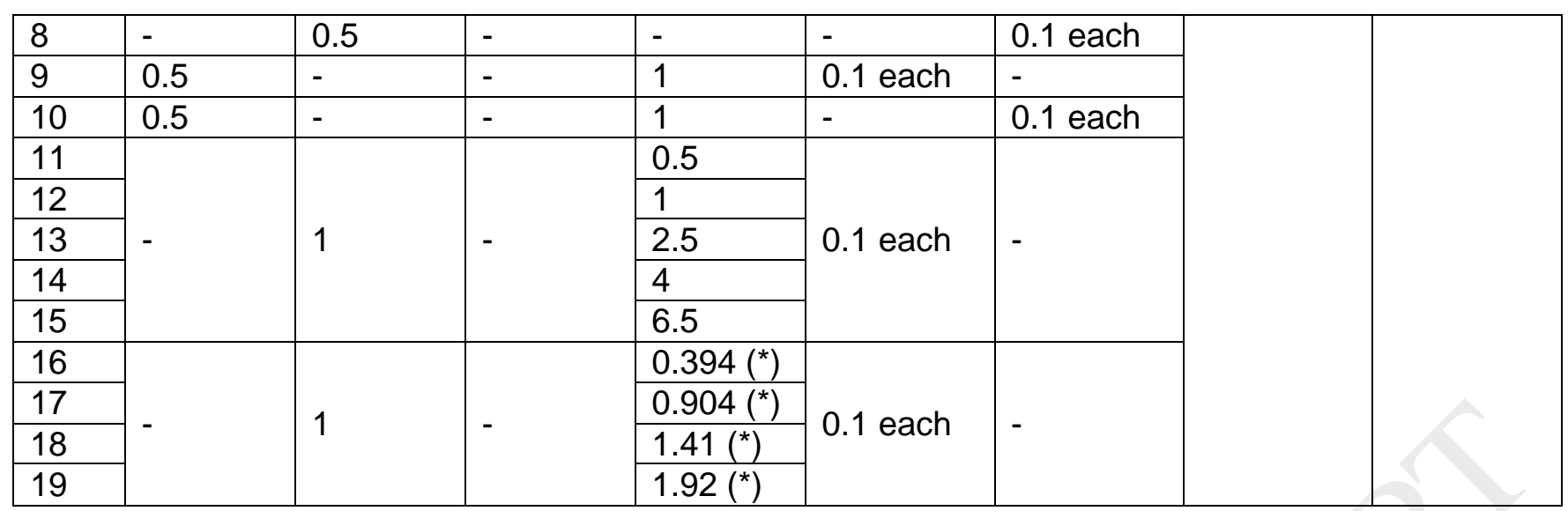

The different sets of concentrations and species were appropriately chosen to examine the influence of sulphuric acid dissociation and the influence of the buffer at constant ionic strength, which is known to have an important influence of the kinetics of reaction 2.

The di-acid $\mathrm{H}_{2} \mathrm{SO}_{4}$ was then compared to the monoacid $\mathrm{HClO}_{4}$ to study the partial dissociation of sulphuric acid.

Different sodium salts, $\mathrm{Na}_{2} \mathrm{SO}_{4}$ and $\mathrm{NaClO}_{4}$, were also tested to study the potential basic behaviour of sulphate. And two buffer systems, $\mathrm{NaH}_{2} \mathrm{BO}_{3}$ and $\mathrm{Na}_{2} \mathrm{HPO}_{4}$, were also compared.

Experiments were carried out in a $1 \mathrm{~L}$ stainless steel standard stirred vessel equipped with two baffles and an inclined blade turbine. Stirring speed was controlled with the aid of a Eurostat 20 Digital (IKA), and temperature was maintained at $25.0^{\circ} \mathrm{C}$ thanks to a double jacket connected to a Ministat 230 (Huber). An amount of $2 \mathrm{~mL}$ of acid solution was injected in the mobile discharge area, at the same height as the turbine and a radial distance of 0.8 times the vessel radius from the shaft. Feed was provided by a peristaltic pump (Masterflex L/S Digital Drive with a Masterflex L/S Easy-Load 3 head pump, Cole-Parmer) through an injection tube with an internal diameter of $1 \mathrm{~mm}$. Absorbance at $353 \mathrm{~nm}$, which can be directly correlated to the concentration in triiodide, was measured by UV-visible spectrophotometry (AvaSpecULS2048LTEC-USB2, with an AvaLight DH-S-DUV light source, both by Avantes). Samples were taken 5 minutes after the beginning of the injection.

If the injection flowrate is too high, the injection time will be smaller than the characteristic meso- and/or macromixing times (Bałdyga and Pohorecki, 1995). In that case, the reactions will be affected by meso- and/or macromixing, leading to greater triiodide productions for higher injection flowrates. Therefore, the injection flowrate has been gradually increased (Guichardon and Falk, 2000), without any significant variation of the absorbance (Fig. 1). It can therefore be concluded that mixing is only controlled by the last micromixing step. All the experiments were carried out at an intermediate injection flowrate of $0.040 \mathrm{~mL} \cdot \mathrm{s}^{-1}$. 


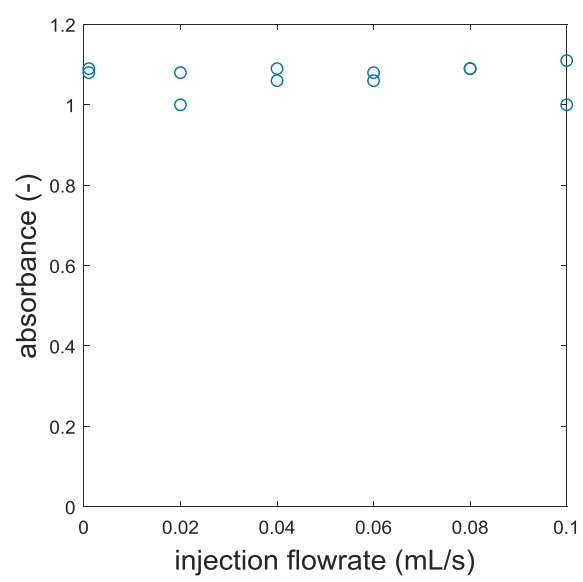

Figure 1: Influence of the injection flowrate on absorbance at $353 \mathrm{~nm}$, for $2 \mathrm{~mL}$ of acid. [ $\left.\mathrm{HClO}_{4}\right]$ $=1 \mathrm{~mol} / \mathrm{L} ;\left[\mathrm{H}_{2} \mathrm{BO}_{3}{ }^{-}\right]=0.1 \mathrm{~mol} / \mathrm{L} ;[\mathrm{KI}]=0.0116 \mathrm{~mol} / \mathrm{l} ;[\mathrm{KIO} 3]=0.0233 \mathrm{~mol} / / ; \mathrm{N}=180 \mathrm{rpm}$

Classical data analysis (Guichardon and Falk, 2000) in the Villermaux-Dushman method includes converting absorption at $353 \mathrm{~nm}$ into triiodide concentration by using the molar extinction coefficient at this wavelength, and then determining a segregation index, $\mathrm{X}_{\mathrm{S}}$, and/or micromixedness ratio, $\alpha$. However, the determination of both $X_{s}$ and $\alpha$ requires a precise estimation of the proton concentration available in the feed. As it will be seen in section 3.1, sulphuric acid is not fully dissociated when it is injected into the vessel, and the estimation of the proton concentration is not trivial. Hence, only absorbance (which can be directly related to triiodide concentration) will be considered here.

\section{Results}

\subsection{Influence of the acid choice}

The influence of the acid solution composition on the triiodide production (and thus, on the absorbance at $353 \mathrm{~nm}$ ), when using a borate buffer is shown in Fig. 2 (left). In all cases, triiodide production decreases when increasing the stirring speed. As expected, a higher stirring speed increases the rate of energy dissipation and so decreases the micromixing time. Results comparison for concentration sets $1\left(0.5 \mathrm{~mol} / \mathrm{L} \mathrm{H}_{2} \mathrm{SO}_{4}\right)$ and $3(1 \mathrm{~mol} / \mathrm{L} \mathrm{HClO}$ ) shows a higher triiodide production for set 3 . When comparing experiment sets $1\left(0.5 \mathrm{~mol} / \mathrm{L} \mathrm{H}_{2} \mathrm{SO}_{4}\right)$ and $4\left(0.5 \mathrm{~mol} / \mathrm{L} \mathrm{HClO}_{4}\right)$, it can be seen that triiodide production is lower for set 4 . These results show the occurrence of the second dissociation of sulphuric acid in experiment set, even if it is not complete. They are in agreement with those of Kölbl and Schmidt-Lehr (2010) who were the first to study the influence of the acid choice.

The behaviour of the sulphuric acid solutions can be better understood if we consider that, according to Bałdyga and Bourne (1989), engulfment controls micromixing for moderate viscosities (Sc $<4$ 4000). Large blobs of the acid solution are deformed and broken up, becoming long and thin slabs that expand engulfing the vessel fluid (Bałdyga and Pohorecki, 1995). Given the second dissociation constant of the sulphuric acid, $\mathrm{pK}_{\mathrm{a}}=1.99$ (Skoog et al, 1996), the initial composition of these slabs is the following: $0.51 \mathrm{~mol} / \mathrm{L} \mathrm{H}^{+}, 0.49 \mathrm{~mol} / \mathrm{L} \mathrm{HSO}_{4}^{-}$, $0.01 \mathrm{~mol} / \mathrm{L} \mathrm{SO}_{4}{ }^{2-}$, at least as a first approximation (the actual pKa value is certainly different at this high electrolyte concentration). As the fluid from the vessel is incorporated, proton concentration decreases through both dilution and consumption (reactions 1 and 2). Thus, $\mathrm{pH}$ 
increases, leading to further dissociation of the $\mathrm{HSO}_{4}^{-}$anions into protons and finally, further triiodide production.
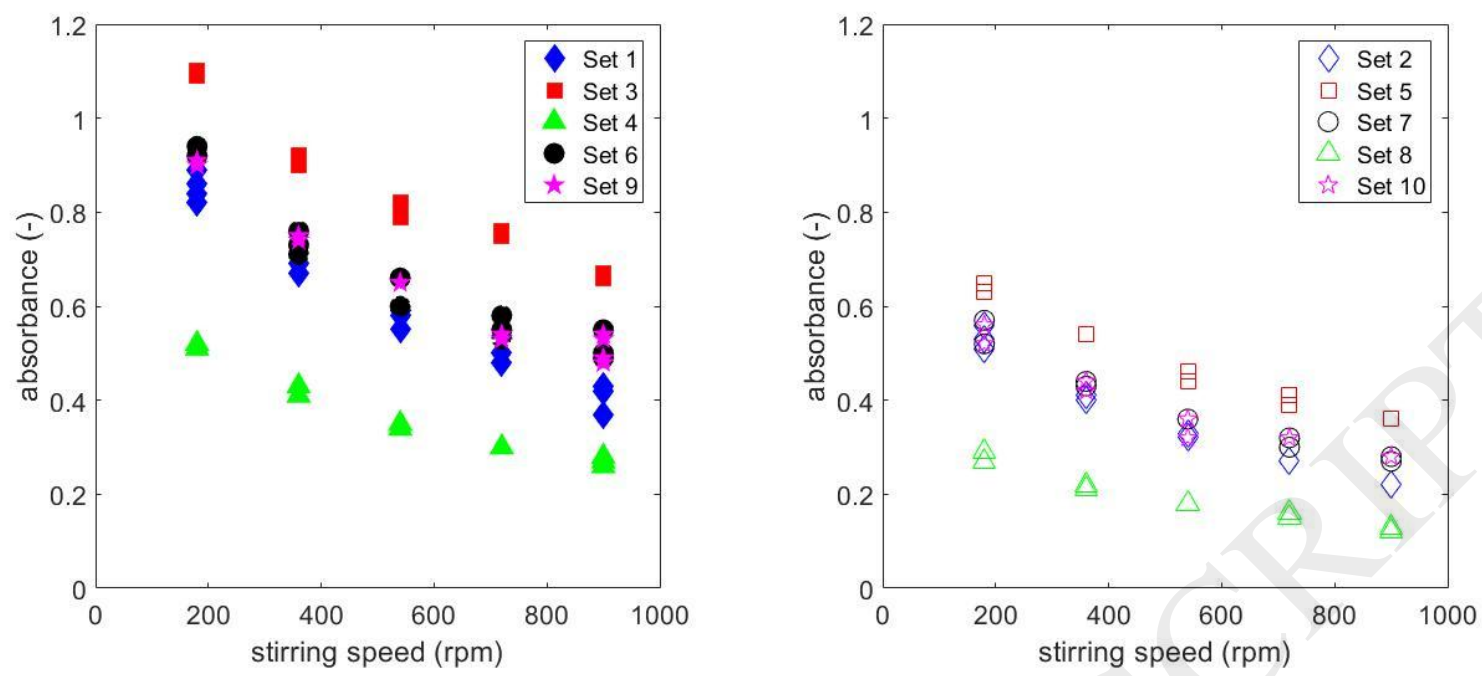

Figure 2: Influence of the stirring speed on absorbance at $353 \mathrm{~nm}$, for different concentration sets using $\mathrm{H}_{3} \mathrm{BO}_{3} / \mathrm{H}_{2} \mathrm{BO}_{3}{ }^{-}$(left) or $\mathrm{H}_{2} \mathrm{PO}_{4}{ }^{-} / \mathrm{HPO}_{4}{ }^{-2}$ (right) as buffer. (The interactive figure is available in the online article)

Let us now compare experiment sets 6 and 9. Both curves closely overlap, showing similar triiodide production. This similar behaviour has been confirmed by using a General Linear Model (Saporta, 2006) described in Appendix B. Given the high p-value of 0.88 , the hypothesis that the two curves are actually the same cannot be dismissed. This is consistent with the fact that both experiment sets include the same concentration of each ion, even if they have been introduced in a different way. This means that sulphate anions act as a base in experiment 6 , which confirms the observations made by Kölbl et al (2013a).

When comparing experiments 1 and 6 , it can be observed that roughly the same amount of triiodide is produced, although slightly lower in experiment 1 . This difference is statistically significant, as it can be deduced from the low $p$-value $\left(9.4 \cdot 10^{-4}\right)$. Although the initial proton concentrations are the same for both experiment sets (Appendix $A$ ), the ionic strengths are different. This seems to indicate a slight influence of the ionic strength, which is confirmed by the comparison of experiments 1 and 9 . For both concentration sets, the same acid is at the same concentration, but concentration set 9 includes $1 \mathrm{~mol} / \mathrm{L}$ of sodium perchlorate. The low $p$-value $\left(9.6 \cdot 10^{-5}\right)$ enables us to consider that the difference between both curves is significant.

As Pinot et al (2014) have proposed using a phosphate buffer instead of the borate buffer, the influence of the composition of the acid solution on triiodide production in the case of phosphate buffer use was also studied, and the results are shown in Fig. 2 (right). The trends are the same as when a borate buffer is: triiodide production decreases again when the stirring speed is increased; the hydrogen sulphate dissociation is not complete (experiments 2 and 5), but it is significant (experiments 2 and 8); the triiodide production is the same if the ion concentrations in the solution are the same, no matter how they are introduced (experiments 7 and 10; $p$-value $=0.65$ ); and finally, sulphate anions have a basic character at low $\mathrm{pH}$ values (comparison of experiments 2 vs 10, and 2 vs 7). However, the influence of the ionic strength is not so obvious: experiments 2 and 7 are significantly different ( $p$-value $=0.025)$, whereas experiments 2 and 10 may not ( $p$-value $=0.12)$ Thus, the influence of the ionic strength will be 
further discussed in section 3.2, before considering the influence of the buffer choice in section 3.3.

\subsection{Influence of the ionic strength}

Comparison between experiments 1 and 9, and experiments 2 and 10, respectively, seems to indicate a slight influence of the ionic strength on triiodide production, with higher ionic strengths leading to slightly higher triiodide productions. To confirm this trend, the ionic strength was modified by adding $\mathrm{NaClO}_{4}$ to the acid solution before injection (Experiments sets 11 to 15), and results are shown in Fig. 3. There is a slight increase in triiodide production for higher ionic strengths. This increase was verified by applying a one-way analysis of variance (ANOVA; Navidi, 2015); the obtained $p$-value $=2.5 \cdot 10^{-10}$ enables us to confirm that the ionic strength in the acid solution influences the triiodide production. This conclusion opposes that of Kölbl et al (2013a), who did not observe a significant influence of the ionic strength.

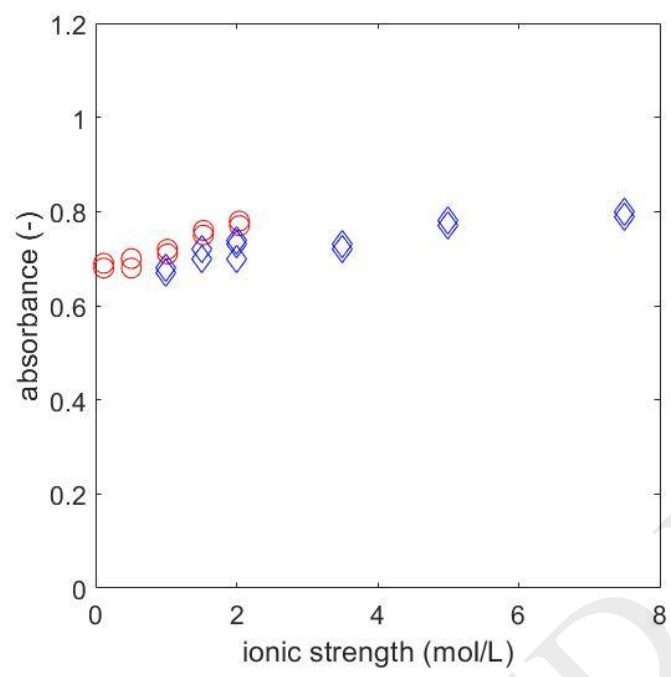

Figure 3: Influence of the ionic strength on absorbance at $353 \mathrm{~nm}$. $\diamond$ : Ionic strength change concerns the acid solution; $\circ$ : lonic strength change concerns the pre-mixture solution. (The interactive figure is available in the online article)

When $\mathrm{NaClO}_{4}$ was added to the pre-mixture solution (Experiments sets 16 to 19), a slight increase in triiodide production with increasing ionic strength was again observed. Once again, the one-way ANOVA confirmed this influence of the ionic strength ( $p$-value $=8.3 \cdot 10^{-7}$ ). This effect was not observed by Kölbl et al (2013a); one possible explanation is that the range of ionic strengths that they tested was narrower than ours.

The influence of the ionic strength might be attributed to two different mechanisms. First, the ionic strength affects the activity coefficients, thus altering both the dissociation constant of the boric acid and the self-ionization constant of the water; therefore, the $\mathrm{H}_{2} \mathrm{BO}_{3}{ }^{-}$concentration in the pre-mixture solution might be slightly modified when the ionic strength in this solution is increased. Second, the evolution of the activity coefficients with the ionic strength impacts the Dushman reaction rate, although this influence might be not monotonic (Barton and Wright, 1968). Further comprehension of these mechanisms would thus require a fine modelling of the 
thermodynamics of these solutions and a reliable kinetic law for the Dushman reaction. This will be the purpose of an upcoming paper.

\subsection{Influence of the buffer choice}

The influence of the buffer choice is shown in Fig. 4. When comparing results for concentration sets 1 and 2, and concentration sets 3 and 5, respectively, it can be seen that triiodide production is significantly higher when a borate buffer is used. This result was actually unexpected since the same buffer concentration was used. Moreover, the $\mathrm{H}_{2} \mathrm{BO}_{3}{ }^{-} / \mathrm{H}_{3} \mathrm{BO}_{3}$ buffer has a higher $\mathrm{pK}_{\mathrm{a}}$ value (9.24, see Table 2$)$; iodine and triiodide are actually thermodynamically unstable in this buffer, although iodine disproportionation is slow enough for the experiments to be free of error (Guichardon and Falk, 2000). On the other hand, $\mathrm{H}_{2} \mathrm{PO}_{4}{ }^{-} / \mathrm{HPO}_{4}{ }^{2-}$ buffer has a lower $\mathrm{pK}_{\mathrm{a}}$ value (7.20, Table 2), which is much closer to the $\mathrm{pH}^{*}$ at which iodine and triiodide are stable (Fournier et al, 1996a). Therefore, iodine and triiodide are much more stable in phosphate buffers, and the difference between both measurements could not be assigned to the thermodynamic stability of iodine.

Table 2: Dissociation constants at $25^{\circ} \mathrm{C}$ for boric and phosphoric acid (Skoog et al, 1996)

\begin{tabular}{|l|l|l|l|}
\hline Acid & $\mathrm{pK}_{\mathrm{a}, 1}$ & $\mathrm{pK}$ & $\mathrm{pK}, 2$ \\
\hline $\mathrm{H}_{3} \mathrm{BO}_{3}$ & 9.24 & - & - \\
\hline $\mathrm{H}_{3} \mathrm{PO}_{4}$ & 2.15 & 7.20 & 12.35 \\
\hline
\end{tabular}

One explanation might be given by a potential catalytic effect of the buffer. Barton and Wright (1968) observed a catalytic effect of different bases, including $\mathrm{HPO}_{4}{ }^{2-}$ and $\mathrm{H}_{2} \mathrm{PO}_{4}^{-}$, on the Dushman reaction. Moreover, the catalytic rate constant seemed to follow a Brönsted law, meaning that the catalytic effect should increase when dealing with stronger bases (higher $\mathrm{pK}_{\mathrm{a}}$ values). One could then expect a catalytic effect of the $\mathrm{H}_{2} \mathrm{BO}_{3}{ }^{-}$anions, stronger than that of the $\mathrm{HPO}_{4}^{-2}$ and $\mathrm{H}_{2} \mathrm{PO}_{4}^{-}$anions, since $\mathrm{H}_{2} \mathrm{BO}_{3}^{-}$is the strongest base. This would explain the enhanced triiodide production when using borate buffers. However, according to Schmitz (1999), this catalytic effect is owed to a reaction between the base ( $\left.\mathrm{B}^{-}\right)$and $\mathrm{I}_{2} \mathrm{O}_{2}$, which is an intermediate species in the Dushman reaction mechanism. This seems unlikely in micromixing experiments, if we consider the mechanism of micromixing (Bałdyga and Pohorecki, 1995): as soon as the base $\mathrm{B}^{-}$is incorporated in the thin slabs containing the acid solution, the $\mathrm{B}^{-}$anions are consumed by the neutralization reaction (reaction 1 ). Thus, the Dushman reaction (reaction 2) can only take place in the case of an excess of protons, when all the $B^{-}$has been consumed already. Thus, the catalytic effect of the buffer could probably be neglected in our case. 


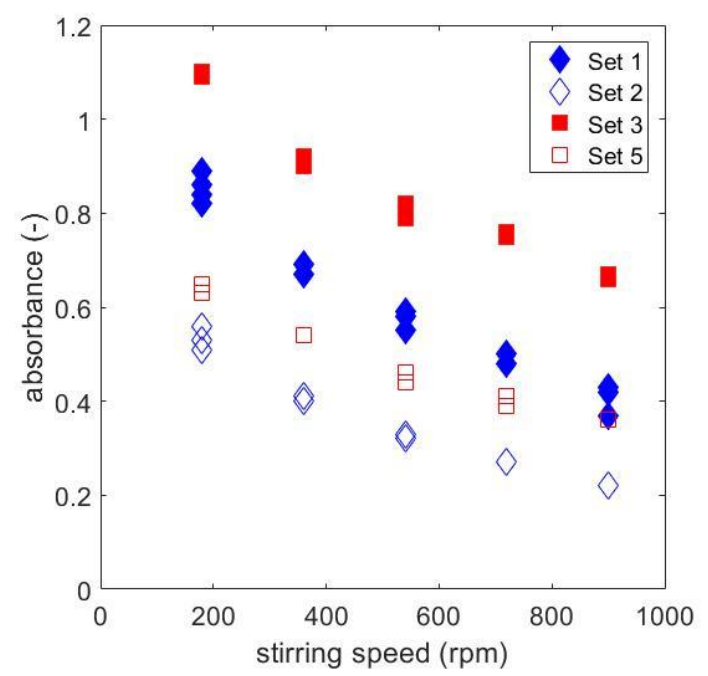

Figure 4: Influence of the buffer choice on absorbance at $353 \mathrm{~nm}$. . (The interactive figure is available in the online article)

Another explanation, which seems to us more likely, is that both $\mathrm{H}_{2} \mathrm{PO}_{4}{ }^{-}$and $\mathrm{HPO}_{4}{ }^{2-}$ act as a base. Indeed, when the acid is injected, the local $\mathrm{pH}$ is low and smaller than the $\mathrm{pK}_{\mathrm{a}}$ for the third dissociation of phosphoric acid ( $\mathrm{pK}_{\mathrm{a}}=2.15$, Table 2). Thus, both anions act as a base at the beginning, leading to higher proton consumptions and thus reducing the iodine production (although later, when the $\mathrm{pH}$ becomes greater than 2.15 as a consequence of the engulfment, $\mathrm{HPO}_{4}{ }^{2-}$ turns out to be the only base of the system).

\section{Discussion}

The experiments show that the acid and buffer choice has a great influence on iodine and triiodide production. However, the same trends (decreasing absorbance with increasing stirring speed, i.e., with decreasing micromixing time) are obtained in all cases. Thus, the influence of the acid and buffer choice on triiodide production should not be a criterion of choice when carrying out qualitative studies. Both phosphate and borate buffers could be used, but two considerations should be taken into account. On the one hand, iodine and triiodide are more stable in a phosphate buffer, since its $\mathrm{pK}_{\mathrm{a}}$ is closer than the $\mathrm{pK}_{\mathrm{a}}$ for borate to the $\mathrm{pH}^{\star}$ at which iodine and triiodide are thermodynamically stable. On the other hand, boric acid is reprotoxic. Therefore, a phosphate buffer would probably be a better choice if the Villermaux Dushman method is only used for qualitative studies.

For qualitative purposes, both sulphuric or perchloric acids may be used preferably, since the same trend is obtained for both (Fig. 2). However, it should be pointed out that perchloric acid and perchlorates are oxidants. Their oxidizing power in aqueous solutions is very little at room temperature because of kinetic activation barriers, but they become vigorous oxidants when heated (Greenwood and Earnshaw, 1997). Thus, perchloric acid use in the Villermaux Dushman method should be limited to room temperature, as it could oxidize iodide into iodine and iodine into iodate at higher temperatures.

If the Villermaux Dushman method is used for quantitative purposes (i. e., to estimate the micromixing time), the combination of perchloric acid and borate buffer is probably a more appropriate choice. Indeed, estimating micromixing times needs using a micromixing model (Bałdyga and Bourne, 1989; Villermaux and Falk, 1994; Fournier et al, 1996b; Lemenand et 
al, 2017) and the kinetics of the Dushman reaction. Since sulphuric acid is an incompletely dissociated acid, the micromixing model should take into account its dissociation constant. The same reasoning applies to phosphate buffers: both $\mathrm{H}_{2} \mathrm{PO}_{4}{ }^{-}$and $\mathrm{HPO}_{4}{ }^{-2}$ have the role of a base in the first moments, but as long as the acid volume incorporates the vessel solution and $\mathrm{pH}$ increases, only $\mathrm{H}_{2} \mathrm{PO}_{4}^{-}$will continue to have this role. Therefore, at least the first dissociation constant of phosphoric acid should be considered in the model. This renders the calculations much more complicated. Moreover, the acid solution is quite concentrated ( $1 \mathrm{~mol} / \mathrm{L})$, meaning that the dissociation constants for ideal diluted solutions, which can be easily found in the literature, should not be used. The activity coefficients should be taken into account, rendering calculations even more tedious. A new model taking into account the dissociation constants of the sulphuric and phosphoric acids will be the goal of another paper.

\section{Conclusion}

The Villermaux-Dushman test for characterising micromixing effects through triiodide production gives qualitatively consistent results, whatever the acid and buffer chosen. In the case of quantitative purposes (micromixing time determination), the precise estimation of the real chemical operating conditions is of prime importance; perchloric acid and borate buffer are probably a wiser choice but a quantitative application also requires reliable kinetics data. The kinetics of the Dushman reaction (reaction 2) obtained by Guichardon et al (2000) is often used in quantitative studies. However, it has been the object of discussions (Bourne, 2008; Kölbl, 2008; Kölbl et al, 2013a, 2013b). Since the strengthening of the Villermaux-Dushman test deserves further investigation into the influence of the acid choice on the kinetics, it will be the main purpose of a next paper.

\section{Funding}

This work was supported by the Ministère de l'Éducation Nationale, de l'Enseignement Supérieur et de la Recherche : DRRT Provence-Alpes-Côte d'Azur [programme 0172]

\section{Appendix A: Estimation of the proton concentration in solutions containing sulphate and hydrogen sulphate anions}

The proton concentration in the sulphuric acid solutions which are being injected can be estimated in the following way (Skoog et al, 1996). First of all, let us consider the case where the injected acid is sulphuric acid. It can be considered as completely dissociated in hydrogen sulphate and protons:

$$
\mathrm{H}_{2} \mathrm{SO}_{4} \rightarrow \mathrm{H}^{+}+\mathrm{HSO}_{4}^{-}
$$

(reaction A1)

Hydrogen sulphate can be further dissociated in sulphate anions and protons:

$$
\mathrm{HSO}_{4}^{-} \leftrightarrow \mathrm{H}^{+}+\mathrm{SO}_{4}^{2-}
$$

(reaction A2)

Reaction A2 is actually an equilibrium, with a characteristic equilibrium constant:

$$
K_{a}=\frac{\left[\mathrm{H}^{+}\right]\left[\mathrm{SO}_{4}^{2-}\right]}{\left[\mathrm{HSO}_{4}^{-}\right]}
$$

The mass balance of each species takes the following form: 


$$
\begin{aligned}
& {\left[\mathrm{HSO}_{4}^{-}\right]=\mathrm{C}_{\mathrm{a}}-\mathrm{x}} \\
& {\left[\mathrm{SO}_{4}{ }^{2-}\right]=\mathrm{x}} \\
& {\left[\mathrm{H}^{+}\right]=\mathrm{C}_{\mathrm{a}}+\mathrm{X}}
\end{aligned}
$$

where $c_{a}$ is the analytical concentration of the sulphuric acid in the solution, and $x$ is the ratio of the extent of reaction to the solution volume. Combining Eqs. A1 to A4, a following quadratic equation is obtained, leading to the final expression of the proton concentration:

$$
\left[H^{+}\right]=c_{a}+\frac{-\left(c_{a}+K_{a}\right)+\sqrt{\left(c_{a}+K_{a}\right)^{2}+4 K_{a} c_{a}}}{2}
$$

This solution is independent of a possible presence of perchlorate anions.

When perchloric acid is used, and a sulphate salt is added, the sulphate anions will play the role of a base. In this case, the following mass balances are obtained:

$$
\begin{aligned}
& {\left[\mathrm{SO}_{4}^{2-}\right]=\mathrm{Cs}_{\mathrm{s}}-\mathrm{x}} \\
& {\left[\mathrm{HSO}_{4}^{-}\right]=\mathrm{x}} \\
& {\left[\mathrm{H}^{+}\right]=\mathrm{Ca}^{\prime}-\mathrm{x}}
\end{aligned}
$$

where $\mathrm{C}_{\mathrm{a}}$ ' and $\mathrm{C}_{\mathrm{s}}$ are the analytical concentrations of the perchloric acid and the sulphate salt. Combining Eqs. A1 and $A 6$ to $A 8$, the following expression for the proton concentration is obtained:

$$
\left[H^{+}\right]=c_{a}{ }^{\prime}-\frac{\left(c_{s}+c_{a}{ }^{\prime}+K_{a}\right)-\sqrt{\left(c_{s}+c_{a}{ }^{\prime}+K_{a}\right)^{2}-4 c_{a}{ }^{\prime} c_{s}}}{2}
$$

When comparing experimental sets 1 and 6 (or 2 and 7 ), it can be seen that $C_{a}=C_{s}=C_{a} / 2$. In this particular case, Eq. A9 reduces to Eq. A5, that is, proton concentration is the same for both experimental sets. The equivalence of the two equations is a consequence of our choice of the acid and salt concentrations, and is independent of the dissociation constant, $\mathrm{K}_{\mathrm{a}}$.

\section{Appendix B: General Linear Model for the comparison of experiments with different concentration sets.}

The absorbance is a function of two variables: $x_{1}$ (the stirring speed) and $x_{2}$, which is a binary variable (for instance, when comparing concentration sets 6 and $9, x_{2}=0$ for the former and $\mathrm{x}_{2}=1$ for the latter). If we consider a linear model:

$$
y_{i}=\beta_{0}+\beta_{1} x_{1}+\beta_{2} x_{2}+e_{i}
$$

where $y_{i}$ is the absorbance obtained in a given experiment, $\beta_{j}$ are the model coefficients and $\mathrm{e}_{\mathrm{i}}$ is the error in experiment $\mathrm{i}$.

The following vectors and matrix are defined: 


$$
\begin{aligned}
& \mathbf{y}=\left(\begin{array}{lll}
y_{1} & \ldots & y_{n}
\end{array}\right) \\
& \boldsymbol{\beta}=\left(\begin{array}{lll}
\beta_{0} & \beta_{1} & \beta_{2}
\end{array}\right) \\
& \mathbf{e}=\left(\begin{array}{lll}
e_{1} & \ldots & e_{n}
\end{array}\right) \\
& \mathbf{X}=\left(\begin{array}{lll}
1 & x_{1,1} & x_{1,2} \\
\ldots & & \\
1 & x_{n, 1} & x_{n, 2}
\end{array}\right)
\end{aligned}
$$

where $x_{i, j}$ is the value of the variable $x_{j}$ in experiment $i$. Thus, all the $n$ experiments can be summarised in the following equation:

$$
\mathbf{y}=\mathbf{X} \boldsymbol{\beta}+\mathbf{e}
$$

According to Saporta (2006), the vector

$$
\mathbf{b}=\left(\mathbf{X}^{\prime} \mathbf{X}\right)^{-1} \mathbf{X}^{\prime} \mathbf{y}=\left(\begin{array}{lll}
b_{0} & b_{1} & b_{2}
\end{array}\right)
$$

can be used as an estimator of $\beta$.

If there is not any influence of the concentration set on the absorbance, then $\beta_{2}=0$ and the statistic

$$
t_{n-3}=\frac{b_{2}}{\sqrt{\frac{\|\mathbf{y}-\mathbf{X b}\|^{2}}{n-3}\left[\left(\mathbf{X}^{\prime} \mathbf{X}\right)_{33}^{-1}\right]}}
$$

follows a Student's t distribution with n-3 freedom degrees.

Thus, the $p$-value can be evaluated as

$$
\mathrm{p}-\text { value }=2 \cdot \int_{t_{n-3}}^{\infty} t(z) d z
$$

where $t(z)$ is the probability density function of a Student's $t$ distribution.

\section{References}

M. Assirelli, W. Bujalski, A. Eaglesham, A. W. Nienow. Study of Micromixing in a Stirred Tank Using a Rushton Turbine. Comparison of Feed Positions and Other Mixing Devices. Chemical Engineering Research \& Design 80, 855-863 (2002) DOI: 10.1205/026387602321143390

M. Assirelli, W. Bujalski, A. Eaglesham, A. W. Nienow. Intensifying micromixing in a semi-batch reactor using a Rushton turbine. Chemical Engineering Science 60, 2333-2339 (2005) DOI: 10.1016/j.ces.2004.10.041 
M. Assirelli, W. Bujalski, A. Eaglesham, A. W. Nienow. Macro- and micromixing studies in an unbaffled vessel agitated by a Rushton turbine. Chemical Engineering Science 63, 35-46 (2008a) DOI: 10.1016/j.ces.2007.07.074

M. Assirelli, E.J.W. Wynn, W. Buialski, A. Eaglesham, A.W. Nienow. An extension to the incorporation model of micromixing and its use in estimating local specific energy dissipation rates. Industrial \& Engineering Chemistry Research 47, 3460-3469 (2008b) DOI: 10.1021/ie070754n

J. Bałdyga, J.R. Bourne. Simplification of Micromixing Calculations. I. Derivation and Application of New Model. Chemical Engineering Journal 42, 83-92 (1989) DOI: 10.1016/03009467(89)85002-6

J. Bałdyga, R. Pohorecki. Turbulent micromixing in chemical reactors - a review. Chemical Engineering Journal 58, 183-195 (1995) DOI: 10.1016/0923-0467(95)02982-6

A.F.M. Barton, G.A. Wright. Kinetics of the lodate-lodide Reaction: Catalysis by Carboxylate and Phosphate lons. Journal of the Chemical Society A: Inorganic, Physical, Theoretical 0, 2096-2103 (1968) DOI: 10.1039/J19680002096

J.R. Bourne. Comment on the iodide/iodate method for characterising micromixing. Chemical Engineering Journal 140, 638-641 (2008) DOI: 10.1016/j.cej.2008.01.031

J.R. Bourne, O.M. Kut, J. Lenzner. An improved reaction system to investigate micromixing in high-intensity mixers. Industrial \& Engineering Chemistry Research 31, 949-958 (1992) DOI: 10.1021/ie00003a042

J.M. Commenge, L. Falk. Villermaux-Dushman protocol for experimental characterization of micromixers. Chemical Engineering and Processing 50, 979-990 (2011) DOI: 10.1016/j.cep.2011.06.006

S. Dushman. The rate of the reaction between iodic and hydriodic acids. Journal of Physical Chemistry 8, 453-482 (1904) DOI: 10.1021/j150061a001

W. Ehrfeld, K. Golbig, V. Hessel, H. Löwe, T. Richter. Characterization of Mixing in Micromixers by a Test Reaction: single Mixing Unites and Mixer Arrays. Industrial \& Engineering Chemistry Research 38, 1075-1082 (1999) DOI: 10.1021/ie980128d

M.-C. Fournier, L. Falk, J. Villermaux. A new parallel competing reaction system for assessing micromixing efficiency - Experimental approach. Chemical Engineering Science 51, 50535064 (1996a) DOI: 10.1016/0009-2509(96)00270-9

M.-C. Fournier, L. Falk, J. Villermaux. A new parallel competing reaction system for assessing micromixing efficiency - Determination of micromixing time by a simple mixing model. Chemical Engineering Science 51, 5187-5192 (1996b) DOI: 10.1016/S0009-2509(96)003405

N.N. Greenwood, A. Earnshaw. Chemistry of the Elements, $2^{\text {nd }}$ Edition. ButterworthHeinemann, Oxford (1997) 
P. Guichardon, L. Falk. Characterisation of micromixing efficiency by the iodide-iodate reaction system. Part I: experimental procedure. Chemical Engineering Science 55, 4233-4243 (2000) DOI: 10.1016/S0009-2509(00)00068-3

P, Guichardon L. Falk, J. Villermaux. Characterisation of micromixing efficiency by the iodideiodate reaction system. Part II: kinetic study. Chemical Engineering Science 55, 4245-4253 (2000) DOI: 10.1016/S0009-2509(00)00069-5

P. Guichardon, L. Falk, M. Andrieu. Experimental Comparison Of The lodide-lodate And The Diazo Coupling Micromixing Test Reactions In Stirred Reactors. Chemical Engineering Research \& Design 79, 906-914 (2001) DOI: 10.1205/02638760152721433

C. Habchi, T. Lemenand, D. Della Valle, M. Khaled, A. Elmarakbi, H. Peerhossaini. Mixing assessment by chemical probe. Journal of Industrial and Engineering Chemistry 20, 14111420 (2014) DOI: 10.1016/j.jiec.2013.07.026

V. Hessel, H. Löwe, F. Schönfeld. Micromixers - a review on passive and active mixing principles. Chemical Engineering Science 60, 2479-2501 (2005) DOI: 10.1016/j.ces.2004.11.033

A. Kölbl. Further comments on the lodide lodate Reaction Method for characterising micromixing. Chemical Engineering Journal 145, 176-177 (2008) DOI: 10.1016/j.cej.2008.06.003

A. Kölbl, M. Kraut, K. Schubert. The lodide lodate Method to Characterize Microstructured Mixing Devices. AIChE Journal 54, 639-645 (2008) DOI: 10.1002/aic.11408

A. Kölbl, S. Schmidt-Lehr. The iodide iodate reaction method: The choice of the acid. Chemical Engineering Science 65, 1897-1901 (2010) DOI: 10.1016/j.ces.2009.11.032

A. Kölbl, V. Desplantes, L. Grundemann, S. Scholl. Kinetic investigation of the Dushman reaction at concentrations relevant to mixing studies in stirred tank reactors. Chemical Engineering Science 93, 47-54 (2013a) DOI: 10.1016/j.ces.2013.01.067

A. Kölbl, M. Kraut, R. Dittemeyer. Kinetic investigation of the Dushman reaction at concentrations relevant to mixing studies in microstructured cyclone type mixers. Chemical Engineering Science 101, 454-460 (2013b) DOI: 10.1016/j.ces.2013.07.008

T. Lemenand, D. Della Valle, C. Habchi, H. Peerhossaini. Micro-mixing measurement by chemical probe in homogeneous and isotropic turbulence. Chemical Engineering Journal 314, 453-465 (2017). DOI: 10.1016/j.cej.2016.12.001

W. Navidi. Statistics for Engineers \& Scientists, $4^{\text {th }}$ Edition. McGraw-Hill Education, New York (2015)

L. Nouri, J. Legrand, N. Benmalek, F. Imerzoukene, A.-R. Yeddou, F. Halet. Characterisation and comparison of the micromixing efficiency in torus and batch stirred reactors. Chemical Engineering Journal 142, 78,86 (2008). DOI: 10.1016/j.cej.2008.01.030

J. Pinot, J.-M. Commenge, J.-F. Portha, L. Falk. New protocol of the Villermaux-Dushman reaction system to characterize micromixing effect in viscous media. Chemical Engineering Science 118, 94-101 (2014) DOI: 10.1016/j.ces.2014.07.010 
S. Panić, S. Loebbecke, T. Tuercke, J. Antes, D. Bošković. Experimental approaches to a better understanding of mixing performance of microfluidic devices. Chemical Engineering Journal 101, 409-419 (2004) DOI: 10.1016/j.cej.2003.10.026

J.-M. Rousseaux, L. Falk, H. Muhr, E. Plasari. Micromixing Efficiency of a Novel SlidingSurface Mixing Device. AIChE Journal 45, $2203-2213$ (1999) DOI: 10.1002/aic.690451018

G. Saporta. Probabilités, analyse des données et statistique, $2^{\text {nd }}$ Edition. Editions TECHNIP, Paris (2006)

E. Schaer, P. Guichardon, L. Falk, E. Plasari. Determination of local energy dissipation rates in impinging jets by a chemical reaction method. Chemical Engineering Journal 72, 125-138 (1999) DOI: 10.1016/S1385-8947(98)00152-1

D. A. Skoog, D. M. West, F. J. Holler. Fundamentals of analytical chemistry, 7th Edition. Saunders College Publishing, Orlando (1996)

G. Schmitz. Kinetics and mechanism of the iodate-iodide reaction and other related reactions. Physical Chemistry Chemical Physics 1, 1909-1914 (1999) DOI: 10.1039/A809291E

J. Villermaux, L. Falk. A generalized micromixing model for initial contacting of reactive fluids. Chemical Engineering Science 49, 5127-5140 (1994) DOI: 10.1016/0009-2509(94)00303-3 